\title{
HASIL TANGKAPAN SAMPINGAN (BYCATCH DAN DISCARD) PADA ALAT TANGKAP GOMBANG (FILTER NET) SEBAGAI ANCAMAN BAGI KELESTARIAN SUMBERDAYA PERIKANAN
}

\author{
Bycatch and Discard on The Filter Net Fisheries As A Treat on Fisheries Resources \\ Oleh: \\ Nofrizal $^{1 *}$, Romie Jhonnerie ${ }^{2}$, Alit Hindri Yani ${ }^{3}$, Alfin $^{4}$ \\ 1Fakultas Perikanandan Ilmu Kelautan, Universitas Riau.aan_fish@yahoo.com \\ ${ }^{2}$ Fakultas Perikanan dan Ilmu Kelautan, Universitas Riau. romie.jhonnerie@gmail.com \\ ${ }^{3}$ Fakultas Perikanan dan Ilmu Kelautan, Universitas Riau.a_alit@yahoo.com \\ ${ }^{4}$ Fakultas Perikanan dan Ilmu Kelautan, Universitas Riau. alfinbks@gmail.com \\ "Korespondensi: : aan_fish@yahoo.com
}

Diterima: 30 April 2018; Disetujui: 25 Oktober 2018

\begin{abstract}
Filter net has a mesh size in small size pockets of the net. This allows filter net has the potential to be non-selective fishing gear about the fish size and the target species catch. If the fishing gear allowed, hence its existence will ultimately have a negative impact on the sustainability of fisheries resources, especially in coastal waters. The objective of this research is to calculate compositions and proportions of the main catch, bycatch and discard of the filter net. It is expected by knowing the composition and proportion of the main catch, bycatch and discard can provide an overview of the pressure on the stock and sustainability of fisheries resources in waters where it is operated. This research was used survey method. A series of survey activities was conducted directly in the field to identify and count species of filter net's fishing catches. Based on the main catch, bycatch and discard of the filter net, it shows that Sergetes similis is the dominant species caught bythe filter net (98.455\%). The main catch for Escualosa thoracata reaches $1.354 \%$. Besides, the main catches that were caught were Metapenaus monocerus, Parapenaeopsis sp, Panulirus sp and Paneeus monodon with the catch percentage ranging from 0.011 to $0.024 \%$. Percentage of by-catches reached $0.04-0.00004 \%$ of the 24 species caught and the catch removed was around $0.001-0.0005 \%$ of the 3 species caught.
\end{abstract}

Keywords: bycatch, discard, filter net, fisheries resources, main catch

\section{ABSTRAK}

Gombang memiliki ukuran mata jaring pada kantong berukuran kecil. Hal ini memungkinkan alat tangkap gombang berpotensi menjadi alat tangkap yang tidak selektif terhadap ukuran ikan dan jenis yang menjadi sasaran tangkapannya. Apabila alat tangkap ini dibiarkan, maka keberadaannya pada akhirnya akan memberikan dampak yang negatif terhadap keberlanjutan sumberdaya ikan terutama di perairan pantai. Tujuan penelitian ini adalah untuk menghitung komposisi dan proporsi hasil tangkapan utama (main catch), hasil tangkapan sampingan (bycatch) dan hasil tangkapan yang dibuang (discard). Diharapkan dengan mengetahui komposisi dan proporsi hasil tangkapan utama, sampingan dan yang dibuang dapat memberikan gambaran tentang tekanan terhadap stok dan kelestarian sumberdaya perikanan di perairan dimana gombang dioperasikan.Metode yang digunakan dalam penelitian ini adalah metode survei. Serangkaian aktivitas survei dilakukan secara langsung di lapang untuk mengidentifikasi dan 
menghitung jenis spesies yang tertangkap oleh alat tangkap gombang. Berdasarkan persentase hasil tangkapan utama, sampingan dan buangan per jenis, menunjukkan Sergetes similis merupakan spesies yang dominan tertangkap oleh alat tangkap gombang (98,455\%). Hasil tangkapan utama untuk Escualosa thoracata mencapai 1,354\%. Selain itu hasil tangkapan utama yang tertangkap ialah Metapenaus monocerus, Parapenaeopsis sp, Panulirus sp dan Paneeus monodon dengan persentase hasil tangkapan berkisar 0,011-0,024\%. Persentase hasil tangkapan sampingan mencapai $0,04-0,00004 \%$ dari 24 spesies yang tertangkap dan hasil tangkapan yang dibuang berkisar 0,001-0,0005\% dari 3 spesies yang tertangkap.

Kata kunci: bycatch, discard, gombang, sumberdaya perikanan, main catch

\section{PENDAHULUAN}

Gombang termasuk alat penangkapan ikan yang dipasang di perairan pasang surut (tidal traps). Alat tangkap ini dipasang menetap diperairan dengan maksud menyaring ikan atau udang yang tidak mampu berenang melawan arus seperti jenis udang (Penaidae), lomek (Harpodon sp), geleber (Setipinna sp), gonjing (Coilia $s p$ ), layur (Trichiurus $s p$ ) dan lain-lain. Sehingga alat ini juga disebut filter net. Sebenarnya alat tangkap ini memang dirancang dan dibuat untuk menangkap udang oleh nelayan. Meskipun dioperasikan secara menetap, alat tangkap ini memberikan konstribusi yang cukup besar bagi produksi perikanan tradisional di pesisir Provinsi Riau khususnya di Daerah Bagansiapi-api, Pulau Sinaboi, muara Sungai Rokan, Selat Panjang, Bengkalis dan Meskom (Syofyan dan Nofrizal 2005). Meskipun alat tangkap gombang dioperasikan secara pasif atau menetap diperairan, tentunya masih sangat memungkinkan dapat menangkap beberapa jenis ikan yang bukan menjadi tujuan utama penangkapan.

Alat tangkap yang ramah lingkungan hendaknya memiliki selektivitas yang tinggi. Alat penangkapan ikan diharapkan selektif terhadap ukuran maupun juga selektif terhadap spesies yang menjadi sasaran utama alat tangkap tersebut. Alat penangkapan ikan yang tidak selektif tentunya berpengaruh terhadap komunitas dan populasi ikan diperairan. Sehingga pada akhirnya berdampak terhadap stok ikan diperairan atau daerah penangkapan ikan tersebut. Syofyan dan Nofrizal (2005) menyebutkan bahwa alat tangkap gombang berpengaruh terhadap komunitas perairan dan diversifikasi spesies dan rantai makanan. Seperti yang kita ketahui bahwa udang dan ikan-ikan yang berukuran kecil menempati posisi konsumen tingkat kedua yang merupakan pemakan plankton, zooplankton dan mikro organisme lainnya di perairan. Jika terjadi gangguan terhadap komunitas tersebut akan mengakibatkan efek berantai pada rantai makanan seluruh komunitas di perairan. Lebih jauh dapat dijelaskan bahwa hasil tangkapan sampingan adalah hasil tangkapan selain dari target tangkapan utama, ini termasuk semua hewan air lainnya yang secara tidak sengaja terjerat ke dalam alat tangkap. Tidak semua hasil tangkapan sampingan dibuang, hanya ikan-ikan yang tidak bernilai ekonomis yang dibuang baik dalam kondisi hidup maupun mati. Selain karena tidak bernilai ekonomis, peraturan juga melarang nelayan mendaratkan hasil tangkapan sampingan. Hal ini dilakukan untuk menekan jumlah hasil tangkapan sampingan yang dihasilkan dari proses penangkapan yang tidak berwawasan lingkungan.

Hasil kajian Eayrs (2005), menyebutkan bahwa FAO mengestimasi sebanyak lebih kurang 7 ton hasil tangkapan sampingan dibuang kelaut oleh nelayan komersial setiap tahunnya. Kemungkinan hasil tangkapan sampingan alat tangkap gombang termasuk ke dalam data tersebut. FAO Code of Conduct of Responsible Fisheries praktis mengupayakan untuk mewajibkan nelayan di seluruh dunia menekan jumlah hasil tangkapan sampingan dan dampak lingkungan yang diakibatkan dari metode penangkapannya. Secara spesifik, peraturan ini mengharuskan semua negara di dunia untuk menerapkan prinsip dasar pengelolaan perikanan yang berkelanjutan (Fisheries Sustainable Management).

Gombang adalah alat penangkapan ikan tradisional yang relatif popular dioperasikan di pantai timur Provinsi Riau, khususnya di Kabupaten Bengkalis oleh nelayan tradisional setempat. Dilaporkan oleh Dinas Perikanan dan Kelautan setempat, pada tahun 2013 jumlah alat tangkap gombang yang dioperasikan berjumlah 651 unit kemudian mengalami peningkatan 909 unit pada tahun 2016 atau naik sebesar 71,6\%. Rancangan alat tangkap gombang berbentuk kerucut memiliki sayap dan badan dan kantong. Pada bagian kantong mata jaring yang digunakan sangat kecil yaitu berukuran $2 \mathrm{~mm}$. Gombang memiliki ukuran mata jaring pada kantong 
berukuran kecil. Hal ini memungkinkan alat tangkap gombang berpotensi menjadi alat tangkap yang tidak selektif terhadap ukuran ikan dan jenis yang menjadi sasaran tangkapannya.

Sejauh ini belum ada kajian yang memastikan bagaimana sebenarnya komposisi hasil tangkapan alat tangkap gombang tersebut. Oleh karena itu, penelitian ini bertujuan untuk mengidentifikasi komposisi dan proporsi hasil tangkapan utama, sampingan dan yang dibuang pada alat tangkap gombang. Tentunya hal ini diharapkan akan menjadi dasar pada kajiankajian yang berkaitan selanjutnya mengenai tek-nologi penangkapan ikan ramah lingkungan dimasa mendatang, dalam rangka menyukseskan kampanye dunia menekan jumlah hasil tangkapan sampingan yang bisa dikatakan berbahaya bagi keberlanjutan sumberdaya perikanan dan lingkungan perairan.

\section{METODE}

Metode yang digunakan dalam penelitian ini adalah metode survei yaitu dengan melakukan pengamatan secara langsung di perairan penangkapan, mengidentifikasi jenis spesies dan menghitung jumlah setiap spesies yang tertangkap oleh alat tangkap gombang. Penelitian ini dilakukanpada bulan Mei sampai Agustus 2017 di Perairan Selat Bengkalis Kecamatan Bengkalis Kabupaten Bengkalis, Provinsi Riau.Pada periode tersebut merupakan puncak musim penangkapan gombang di perairan Bengkalis. Penetapan lokasi penelitian dilihat dari penyebaran terbesar alat tangkap gombang di Provinsi Riau, yaitu di perairan Selat Bengkalis. Sehingga diharapkan dapat representtatif mengambarkan proporsi dan komposisi hasil tangkapan perikanan gombang di Provinsi Riau.
Gambar 1 menunjukkan lokasi pengoperasian gombang diperairan Desa Meskom, Desa Teluk Lantak dan Desa Kelemantan. Ketiga desa ini merupakan kosentrasi lokasi daerah penangkapan alat tangkap gombang yang terbanyak di Kabupaten Bengkalis. Pengambilan data hasil tangkapan pada alat tangkap gombang menggunakan metode propulsif sampling, yaitu diambil 10 unit alat tangkap gombang. Kemudian dari 10 unit tersebut dipilih 4 unit berdasarkan ukuran yang paling besar, 3 unit ukuran alat tangkap gombang yang menengah dan 3 unit ukuran alat tangkap gombang yang paling kecil (Gambar 2). Diharapkan dari pemilihan ketiga kelompok alat tangkap gombang ini dapat menghasilkan data yang representatif menggambarkan komposisi dan proporsi hasil tangkapan alat tangkap gombang yang terdapat di perairan Provinsi Riau. Dari ketiga kelompok ukuran tersebut diidentifikasi dan dihitung persentase hasil tangkapan utama, sampingan dan yang dibuang.Tabel 1. Jumlah contoh (n) setiap jenis ikan kerapu sunudari genus Plectropomus $\mathrm{sp}$.

Penetapan kriteria hasil tangkapan utama, sampingan dan yang dibuang berdasarkan wawancara terhadap nelayan. Hasil tangkapan utama merupakan hasil tangkapan yang diinginkan oleh nelayan, ketika mereka hendak merancang dan memasang alat tangkap gombang tersebut. Biasanya hasil tangkapan utama memiliki nilai ekonomis yang cukup tinggi. Hasil tangkapan sampingan merupakan hasil tangkapan yang tidak diinginkan oleh nelayan, tetapi hasil tangkapan ini kadang kala masih memiliki nilai ekonomis meskipun tidak begitu tinggi ataupun hasil tangkapan tersebut masih dapat dikonsumsi oleh nelayan. Adapun hasil tangkapan yang dibuang adalah hasil tangkapan yang tidak diinginkan oleh nelayan dan tidak memiliki nilai ekonomis, bahkan hasil tangkap-

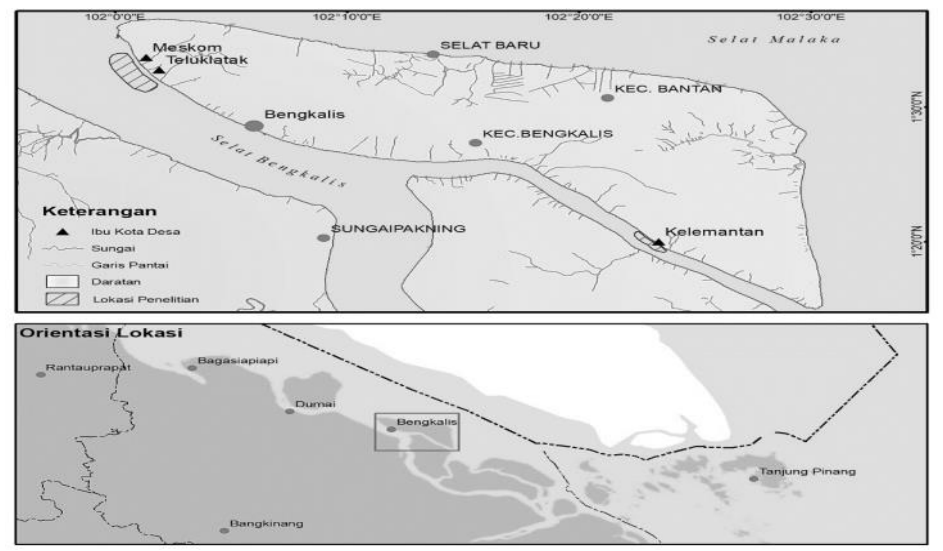

Gambar 1 Peta lokasi penelitian. Poligon yang diarsir menunjukan lokasi pengambilan hasil tangkapan gombang 


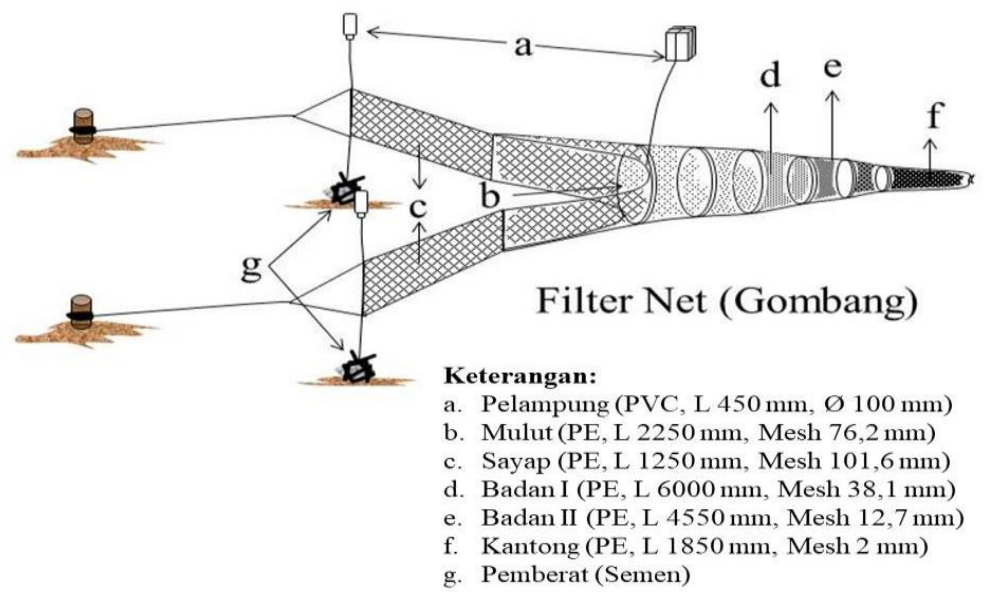

Gambar 2 Konstruksi alat tangkap gombang yang dioperasikan oleh nelayan di Desa Meskom dan Desa Kelemantan.

an ini dibuang oleh nelayan dalam keadaan hidup ataupun mati.

Total hasil tangkapan dari setiap pemasangan alat tangkap gombang dikumpulkan, kemudian dipisahkan berdasarkan jenis dan dihitung jumlah. Hal ini dilakukan untuk menentukan persentase jumlah hasil tangkapan per jenis, sehingga dapat diketahui proporsi dari besarnya hasil tangkapan utama, sampingan maupun hasil tangkapan yang dibuang. Jenis ikan hasil tangkapan dari gombang yang belum diketahui jenisnya diidentifikasi dan dianalisis di laboraturium.

Hasil tangkapan perunit alat tangkap gombang dikumpulkan setiap kali pengangkatan alat tangkap (hauling). Hasil tangkapan tersebut kemudian diidentifikasi berdasarkan kelompok jenis dan dihitung untuk mendapatkan hasil tangkapan per satuan upaya. (Catch Per Unit Effort/CPUE) dengan pendekatan matematis (Andrade et al. 2007).:

$q=\frac{h}{f}$

dengan:

$q=$ CPUE (individu/trip)

$h=$ hasil tangkapan (individu)

$f=$ upaya penangkapan

Kemudian data hasil tangkapan yang diperoleh dianalisis menggunakan analisis statistik deskriptif yang ditampilkan dalam bentuk tabel dan grafik untuk memberikan informasi yang lebih komprehensif antara perbedaan hasil tangkapan utama dengan sampingan setiap kali pengoperasian alat tangkap gombang. Data komposisi hasil tangkapan gombang tersebut juga dianalisis untuk menghitung besarnya ke- limpahan relatif dengan menggunakan persamaan Krebs (1985) sebagai berikut:

Kepadatan Relatif $=\frac{\text { Jumlah individu suatu jenis }}{\text { jumlah individu seluruh jenis }} \times 100 \% \ldots$

Analisis keragaman masing-masing hasil tangkapan yang diperoleh alat tangkap gombang menggunakan uji $F$. Uji $F$ tersebut dilakukan agar dapat melihat keragaman rata-rata setiap spesies yang tertangkap setiap kali penarikan alat tangkap (hauling), dari seluruh sampel alat tangkap gombang yang diamati. Sehingga dapat menjawab hipotesis "hasil tangkapan gombang memiliki keragaman jenis". Adapun pendekatan persamaan uji $F$ tersebut sebagai berikut;

$F=\frac{\frac{R^{2}}{k}}{\left(1-R^{2}(n-k-1)\right.}$

dengan:

$R^{2}=$ koefisien regresi

$n=$ jumlah seluruh sampel ikan hasil tangkapan gombang

$k=$ jumlah setiap spesies tertangkap

\section{HASIL}

Data komposisi dan jumlah hasil tangkapan keseluruhan alat penangkapan ikan gombang setiap kali penarikan sangat penting untuk mendapatkan informasi tingkat efektivitas dan selektivitas terhadap jenis spesies yang ditangkap oleh alat penangkapan ikan gombang tersebut. Berdasarkan pengamatan, terdapat 33 jenis hasil tangkapan gombang. Dari 33 jenis tersebut 6 jenis $(18,182 \%)$ merupakan hasil tangkapan utama, 24 jenis $(72,727 \%)$ hasil tangkapan sampingan dan hasil tangkapan 
yang dibuang 3 spesies $(9,091 \%)$. Data komposisi dan jumlah hasil tangkapan gombang dapat dilihat pada Tabel 1.

Rata-rata hasil tangkapan utama alat penangkapan gombang per unit dan per upaya penangkapan signifikan lebih tinggi dibandingkan hasil tangkapan sampingan dan yang dibuang $(F<0,05)$. Laju hasil tangkapan per unit dan per upaya penangkapan menunjukkan jenis udang Sergetes similis dan ikan Escualosa thoracata lebih tinggi dari pada jenis ikan, crustace dan lainnya $(F<0,05)$. Rata-rata laju tangkapan per unit dan per upaya adalah 20.346,65 $\pm 15.702,05$ ekor untuk udang Sergetes similis dan $331,65 \pm 518,51$ ekor untuk ikan Escualosa thoracata (Gambar 3).

Tabel 1 Komposisi dan jumlah hasil tangkapan utama, sampingan dan yang dibuang.

\begin{tabular}{|c|c|c|c|c|}
\hline No. & Nama lokal & Nama IImiah & $\begin{array}{c}\text { Jumlah hasil } \\
\text { tangkapan } \\
\text { (individual) }\end{array}$ & Keterangan \\
\hline 1 & Udang pepay & Sergestes similis & 2.416 .826 & Main catch \\
\hline 2 & Bilis & Escualosa thoracata & 33.232 & Main catch \\
\hline 3 & Udang putih & Metapenaeus monoceros & 371 & Main catch \\
\hline 4 & Udang merah & Parapenaeopsis sp & 330 & Main catch \\
\hline 5 & Udang duri & Panulirus sp & 583 & Main catch \\
\hline 6 & Udang belang & Penaeus monodon & 267 & Main catch \\
\hline 7 & Bulu ayam & Thryssa mystax & 257 & Bycatch \\
\hline 8 & Lomek & Harpodon nehereus & 304 & Bycatch \\
\hline 9 & Beliak mato & Ilisha elongata & 316 & Bycatch \\
\hline 10 & Gelebei & Ilisha kampeni & 158 & Bycatch \\
\hline 11 & Layur & Trichiurus lepturus & 1.066 & Bycatch \\
\hline 12 & Biang & Setipinna breviceps & 11 & Bycatch \\
\hline 13 & Bawal putih & Pampus argenteus & 42 & Bycatch \\
\hline 14 & Bawal hitam & Parastromateus niger & 2 & Bycatch \\
\hline 15 & Tenggiri & Scomberomorus commerson & 50 & Bycatch \\
\hline 16 & Parang-parang & Chirocentrus dorab & 10 & Bycatch \\
\hline 17 & Belanak & Mugil cephalus & 1 & Bycatch \\
\hline 18 & Gulamah & Otolithoides biauritus & 125 & Bycatch \\
\hline 19 & Selidah & Cynoglossus lingua & 36 & Bycatch \\
\hline 20 & Kitang & Scatophagus argus & 10 & Bycatch \\
\hline 21 & Selangat & Anodontostoma chacunda & 3 & Bycatch \\
\hline 22 & Keke & Secutor insidiator & 167 & Bycatch \\
\hline 23 & Duri & Arius maculaticus & 2 & Bycatch \\
\hline 24 & Jando & Parambassis wolfii & 186 & Bycatch \\
\hline 25 & Korek api & Harpadon microchir & 27 & Bycatch \\
\hline 26 & Sagai & Carangoides sp & 19 & Bycatch \\
\hline 27 & Puput & Ilisha megaloptera & 1 & Bycatch \\
\hline 28 & Snepak & Scylla serrata & 42 & Bycatch \\
\hline 29 & Cumi & Loligo vulgaris & 197 & Bycatch \\
\hline 30 & Kuda laut & Hippocampus denise & 15 & Bycatch \\
\hline 31 & Udang mantis & Squilla mantis & 44 & Discard \\
\hline 32 & Buntal & Colomesus psittacus & 32 & Discard \\
\hline 33 & Kepiting belang & Matuta planipes & 13 & Discard \\
\hline
\end{tabular}




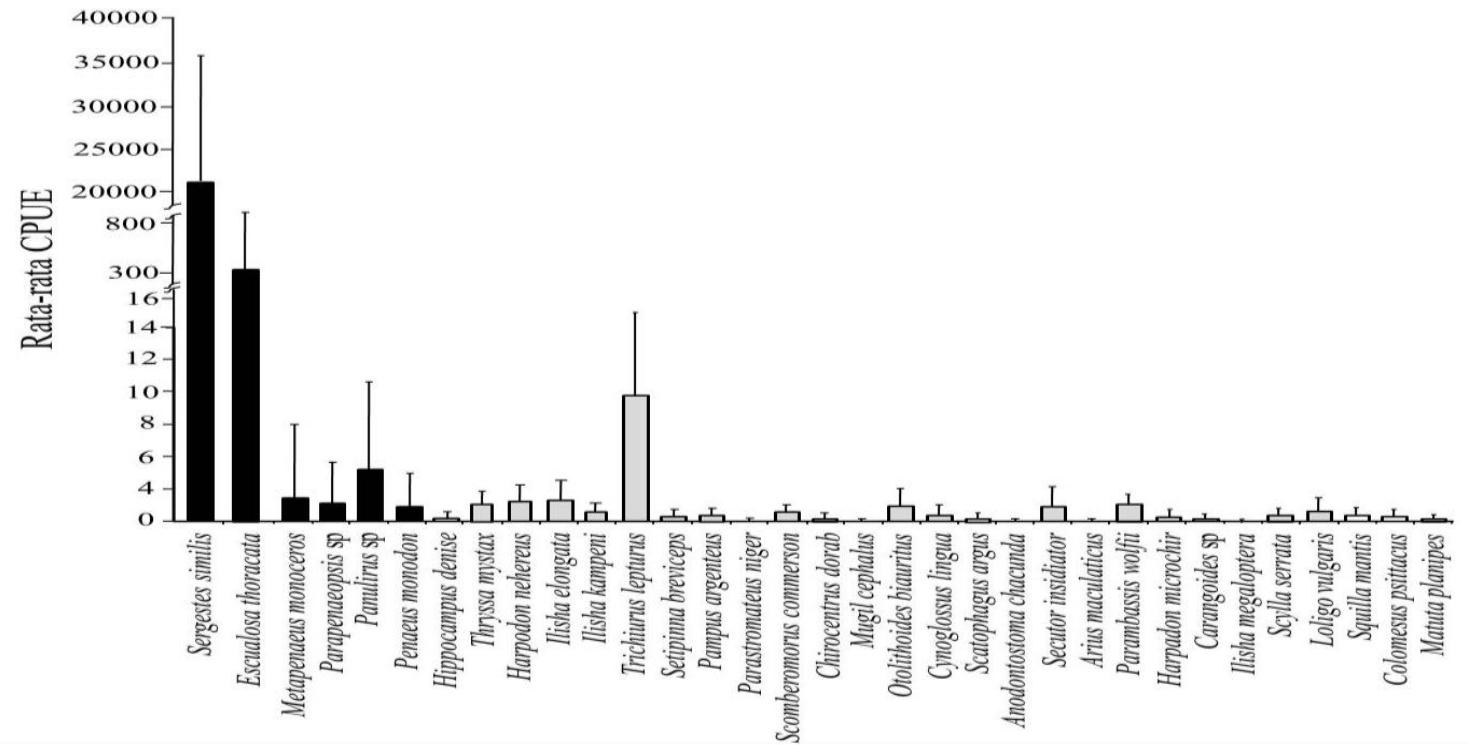

Gambar 3 Rata-rata hasil tangkapan per unit dan per upaya alat penangkapan gombang

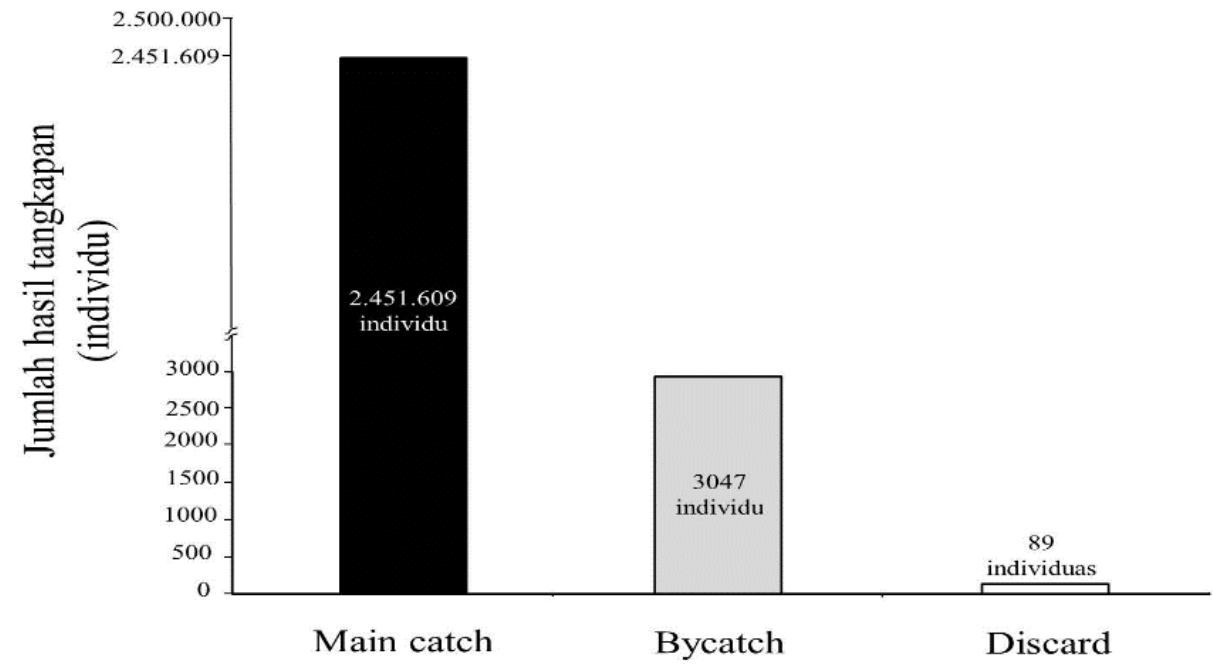

Gambar 4 Perbandingan jumlah total hasil tangkapan utama, sampingan dan hasil tangkapan yang dibuang

Gambar 3 menunjukkan jenis ikan Trichiurus lepturus merupakan jenis yang paling banyak tertangkap pada setiap operasi penangkapan gombang, dengan rata-rata $9,85 \pm 5,40$ ekor. Jenis ikan ini adalah hasil tangkapan sampingan dari alat tangkap gombang. Sedangkan hasil tangkapan per unit alat tangkap gombang yang dibuang cukup rendah (Gambar 3).

Histogram berwarna hitam pada Gambar 3 menunjukkan hasil tangkapan utama. Histogram berwarna abu-abu menunjukkan hasil tangkapan sampingan, dan histogram tidak berwarna menunjukkan hasil tangkapan yang dibuang. Perbandingan antara jumlah total hasil tangkapan utama, hasil tangkapan sampingan dan hasil tangkapan buangan dari 39 kali penarikan alat tangkap. Total hasil tangkapan utama lebih banyak dari pada hasil tangkapan sampingan maupun hasil tangkapan yang dibuang, yaitu sebanyak 2.451.609 individu dari enam spesies yang teridentifikasi sebagai hasil tangkapan utama tersebut. Adapun hasil tangkapan sampingan hanya berjumlah 3.047 individu dari 24 spesies. Hasil tangkapan terendah adalah hasil tangkapan buangan dengan total hasil tangkapan 89 individu dari 3 spesies yang tertangkap (Gambar 4).

Hasil tangkapan utama memang mendominasi total hasil tangkapan alat tangkap gombang dari seluruh operasi penangkapan. Berdasarkan persentasi hasil tangkapan utama, sam- 
pingan dan yang dibuang, menunjukkan Sergetes similis merupakan spesies yang dominan tertangkap, yaitu mencapai 98,455\%. Hasil tangkapan yang dominan lainnya adalah Escualosa thoracata mencapai $1,354 \%$. Selain itu hasil tangkapan utama yang tertangkap adalah Metapenaus monocerus, Parapenaeopsis sp., Panulirus sp., dan Panaeus monodon dengan persentase hasil tangkapan berkisar 0,0110,024\% (Gambar 5).

Grafik histogram pada Gambar 5 menunjukkan dari 24 jenis ikan, udang, dan crustasea yang tertangkap sebagai hasil tangkapan sam- pingan, jenis Trichiurus lepturus merupakan jumlah yang paling banyak tertangkap, yaitu $0,043 \%$. Selain itu, jenis hasil tangkapan sampingan yang dominan tertangkap adalah Harpodon neherus sebanyak 0,012\%, Thryssa mystax sebanyak 0,010\%, dan Ilisha elongata sebanyak 0,013\%.

Histogram berwarna hitam pada Gambar 5 menunjukkan hasil tangkapan utama. Histogram berwarna abu-abu merupakan hasil tangkapan sampingan dan histogram berwarna putih merupakan hasil tangkapan yang dibuang.

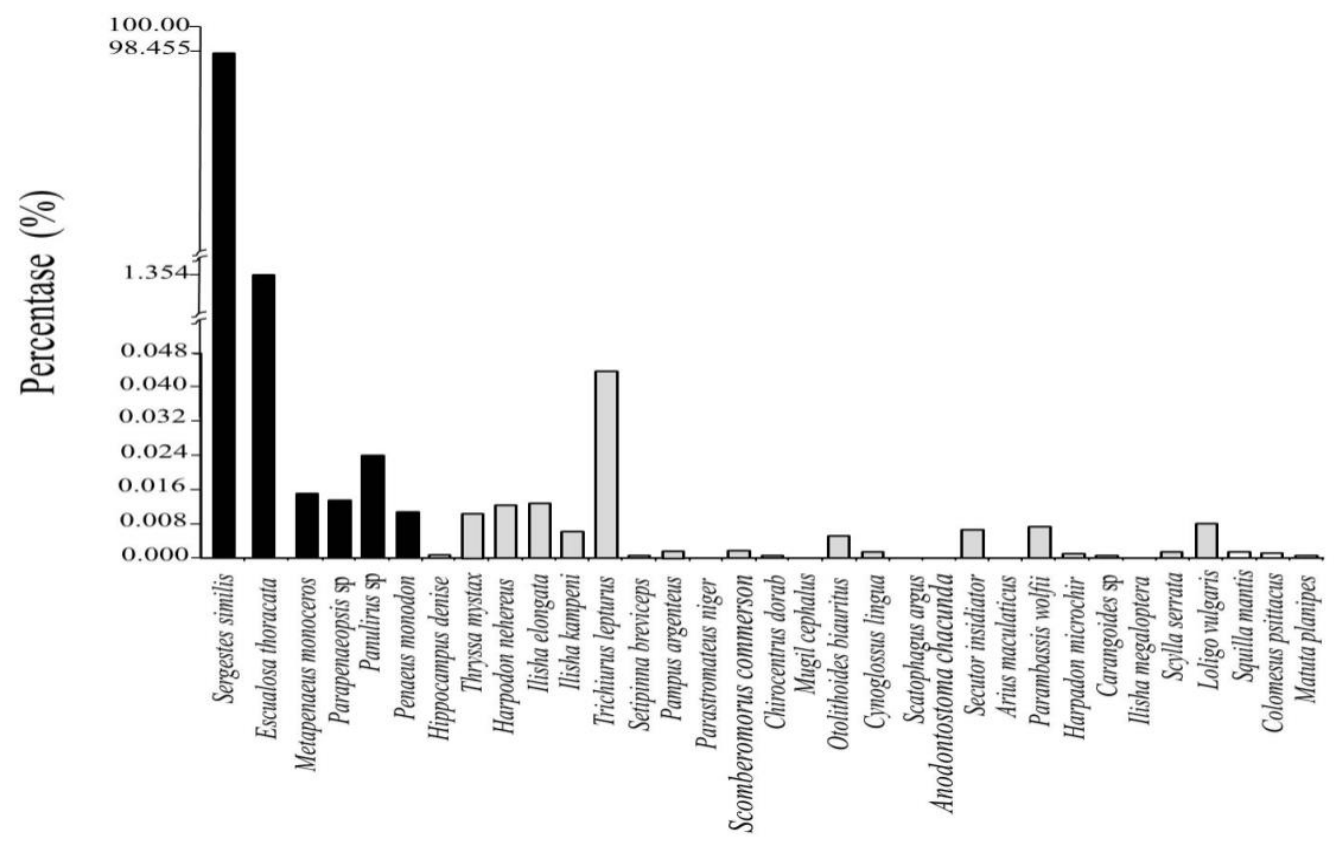

Gambar 5 Persentase jumlah hasil tangkapan utama, sampingan dan yang dibuang

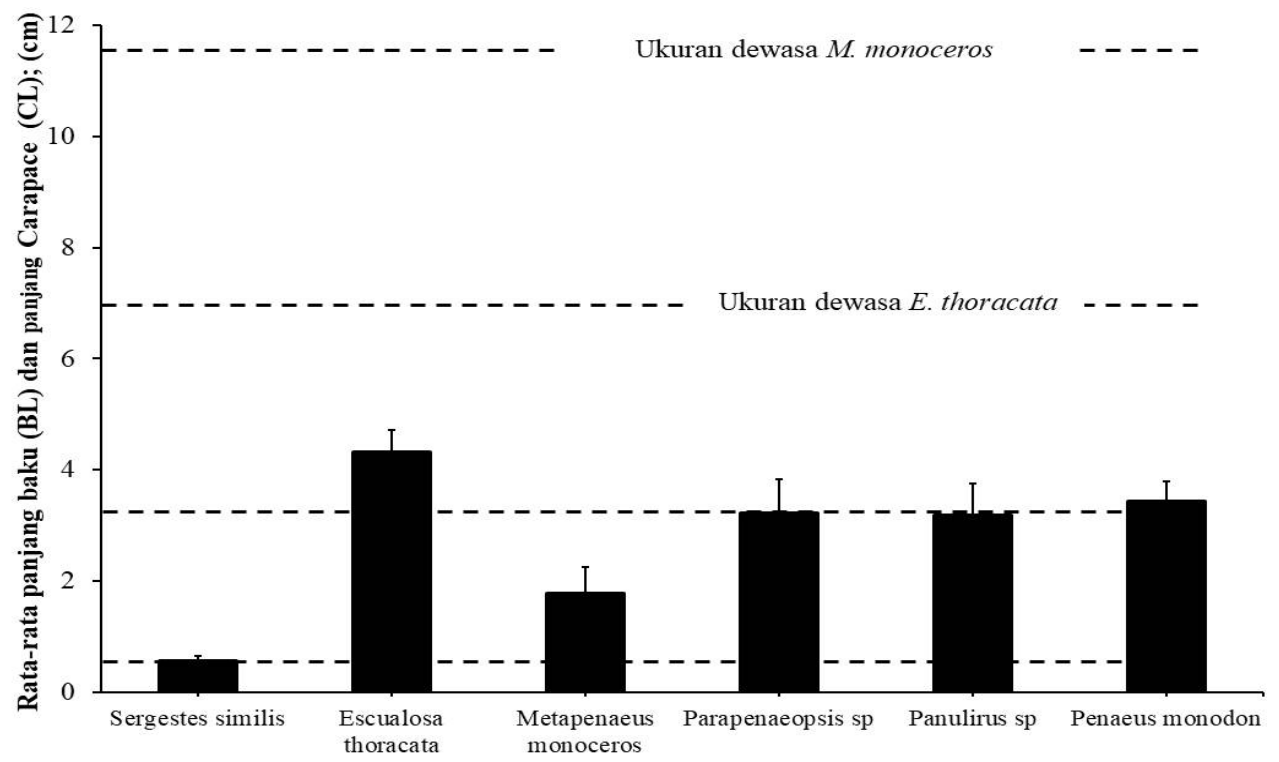

Gambar 6 Rata-rata ukuran ikan yang tertangkap sebagai hasil tangkapan utama 


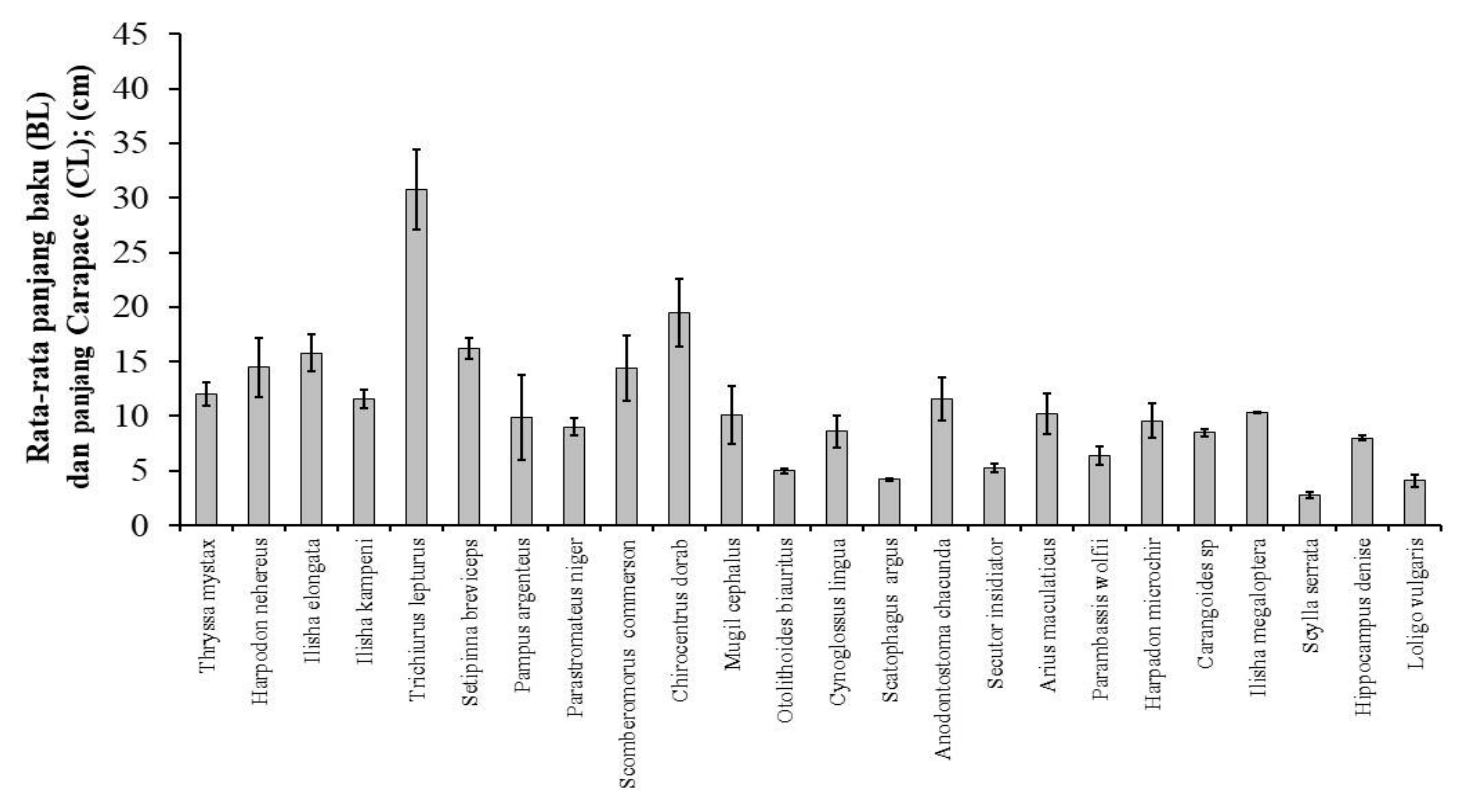

Gambar 7 Panjang rata-rata ukuran ikan yang tertangkap sebagai hasil tangkapan sampingan

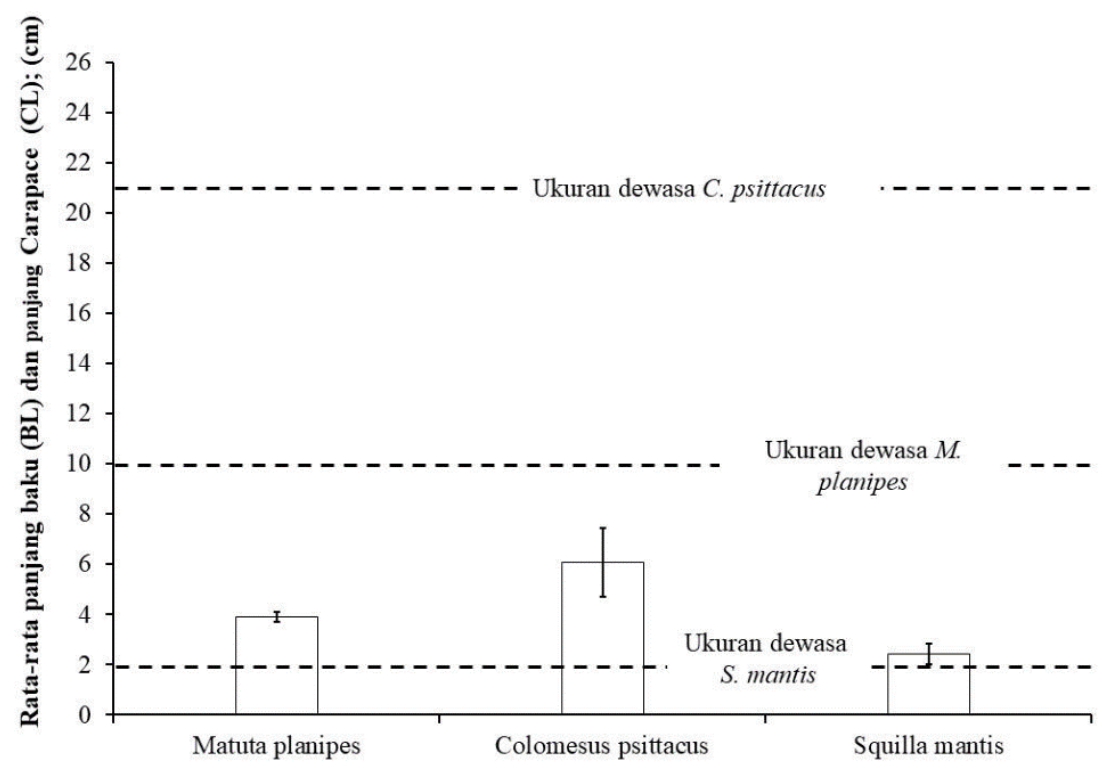

Gambar 8 Rata-rata ukuran ikan yang tertangkap sebagai hasil tangkapan buangan (discard)

Jenis hasil tangkapan sampingan lainnya adalah Pampus argenteus, Parastromateus niger, Scomberomorus commerson, Chirocentrus dorab, Mugil cephalus, Otolithoides biauritus, Cynoglossus lingua, Scatophagus argus, Anodontostoma chacunda, Secutor insidiator, Arius maculaticus, Parambassis wolfii, Harpadon microchir, Carangoides sp, Llisha megaloptera, Scylla serrate, Loligo vulgaris, dan Hippocampus denise dengan persentase berkisar antara 0,00004-0,043\% (Gambar 5).

Ukuran panjang tubuh ikan dan panjang carapace udang dan kepiting menjadi salah satu indikator tingkat kedewasaan pertama (first maturity). Rata-rata ukuran panjang baku ( $\mathrm{Ca}$ rapace Length (CL)) hasil tangkapan utama untuk jenis Sergetes similis $0,57 \pm 0,07 \mathrm{CL}, \mathrm{cm}$ (rata-rata \pm standar deviasi), untuk jenis Escualosa thoracata berukuran $4,32 \pm 0,40 \mathrm{~cm}$, untuk

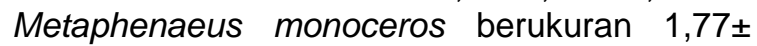
$0,48 \mathrm{~cm}$; Parapenaeopsis sp berukuran $3,23 \pm$ $0,59 \mathrm{~cm}$, Panulirus sp berukuran $3,19 \pm 0,57 \mathrm{~cm}$; dan untuk udang Penaeus monodon berukuran $3,43 \pm 0,37 \mathrm{~cm}$. Hampir seluruh jenis hasil tangkapan utama alat tangkap gombang ini di bawah ukuran tingkat kedewasaan (first maturity) (Gambar 6). 
Grafik histogram pada Gambar 7 menunjukkan hampir seluruh jenis hasil tangkapan sampingan terdiri dari ikan dan udang yang belum dewasa. Hal ini sama dengan fenomena yang terjadi pada ukuran ikan pada hasil tangkapan utama. Hasil tangkapan ikan Harpodon neherus rata-rata ukuran yang tertangkap 14,50 $\pm 2,70 \mathrm{~cm}$; BL, ikan Thryssa mystax berukuran $12,00 \pm 1,09 \mathrm{~cm}$, llisha elongata berukuran 15,80 $\pm 1,69 \mathrm{~cm}$, Pampus argenteus berukuran 9,90 $\pm 3,89 \mathrm{~cm}$, Parastromateus niger berukuran $9,00 \pm 0,78 \mathrm{~cm}$, Scomberomorus commerson

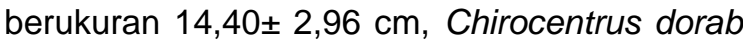

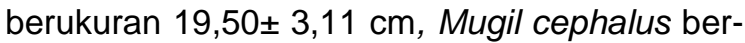
ukuran 10,10 $\pm 2,69 \mathrm{~cm}$, Otolithoides biauritus

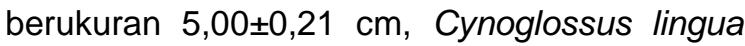
berukuran $8,60 \pm 1,48 \mathrm{~cm}$, Scatophagus argus berukuran $4,20 \pm 0,07 \mathrm{~cm}$, Anodontostoma chacunda berukuran $11,60 \pm 1,98 \mathrm{~cm}$, Secutor insidiator berukuran $5,30 \pm 0,41 \mathrm{~cm}$, Arius maculaticus berukuran 10,20 $\pm 1,84 \mathrm{~cm}$, Parambassis wolfii berukuran $6,40 \pm 0,86 \mathrm{~cm}$, Harpadon microchir berukuran $9,60 \pm 1,57 \mathrm{~cm}$, Carangoides sp berukuran $8,50 \pm 0,35 \mathrm{~cm}$, llisha megaloptera berukuran 10,3 $\pm 0,07 \mathrm{~cm}$, Scylla serrata berukuran 2,80 $\pm 0,25 \mathrm{CL} \mathrm{cm}$, Loligo vulgaris berukuran 4,10 $\pm 0,56 \mathrm{ML} \mathrm{cm}$, dan Hippocampus denise berukuran $8,00 \pm 0,21 \mathrm{~cm}$.

Rata-rata ukuran ikan hasil tangkapan yang dibuang pada alat tangkap gombang lebih kecil dari ukuran dewasa spesies tersebut. Jenis kepiting Matuta planipes rata-rata ukuran yang tertangkap oleh alat tangkap gombang berukuran 3,90 $\pm 0,20, \mathrm{CL} ; \mathrm{cm}$. Sedangkan ukuran mulai dewasa spesies ini berukuran $10 \mathrm{~cm}$ (Gambar 7). Ikan Colomesus psittacus merupakan salah satu hasil tangkapan yang paling banyak tertangkap sebagai hasil tangkapan yang dibuang pada alat tangkap gombang. Rata-rata ukuran ikan Colomesus psittacus yang tertangkap berukuran $6,07 \pm 1,37$, BL; $\mathrm{cm}$. Ukuran tersebut juga lebih kecil dari pada ukuran dewasa pada umumnya yang berukuran panjang tubuh $25 \mathrm{~cm}$. Udang Squilla mantis merupakan hasil tangkapan buangan, dengan rata-rata panjang karapas 2,04 $\pm 0,40, \mathrm{CL} ; \mathrm{cm}$ (Gambar 8).

\section{PEMBAHASAN}

Kemampuan dan tingkah laku renang ikan memegang peranan penting dalam proses tertangkapnya ikan oleh alat penangkapan ikan (Nofrizalet al. 2009; Nofrizal dan Arimoto 2011; Nofrizalet al. 2012; Nofrizal 2014; Nofrizal dan Ahmad 2015; Nofrizal 2015; Nofrizal dan Arimoto 2017). Pada prinsipnya alat penangkapan gombang dipasang pada perairan yang memiliki arus pasang surut yang kuat, seperti selat sehingga alat ini dapat menyaring ikan dan udang yang tidak mampu berenang melawan kecepatan arus sehingga terbawa arus masuk kedalam kantong. Oleh karena itu, sebagian besar hasil tangkapan gombang merupakan udang dan ikan-ikan kecil yang memiliki kemampuan renang yang rendah. Alat tangkap gombang tersebut dipasang di perairan oleh nelayan sesuai dengan sasaran ikan atau udang yang akan ditangkap, yaitu dengan cara mengatur jumlah dan besar pelampung mau-pun pemberat. Menurut Syofyan dan Nofrizal (2005), jenis hasil tangkapan utama dari alat penangkapan gombang ini adalah udang rebon. Selain itu banyak pula tertangkap jenis-jenis udang ( $\mathrm{Pe}$ naidae), lomek (Harpodon sp), geleber (Setipinna $s p$ ), gonjing (Coilia $s p$ ), layur (Trichiurus $s p$ ) dan Iain-lain. Syofyan dan Nofrizal (2005) mengatakan bahwa hasil tangkapan yang diharapkan nelayan adalah udang pepay dan ikan-ikan kecil. Alat tangkap gombang tidak spesifik untuk satu jenis sasaran penangkapan saja, dilihat dari hasil tangkapan yang bermacam-macam jenis ikan kecil sampai sedang dan beberapa jenis udang yang tertangkap.

Gambar 3 dan 4 menunjukkan rata-rata hasil tangkapan gombang per upaya penangkapan memiliki pola yang sama dengan persentase jumlah total hasil tangkapan utama, sampingan dan yang dibuang. Meskipun laju hasil tangkapan per unit alat tangkap gombang tinggi namun jenis spesies sebagai hasil tangkapan sampingan cukup banyak. Hal serupa juga dilaporkan oleh Broadhurst et al. (2006) hasil tangkapan sampingan pada perikanan pukat di perairan tropis tidak proporsional dengan hasil tangkapan utama. Jenis hasil tangkapan sampingan lebih banyak dari pada hasil tangkapan utama. Hasil tangkapan sampingan merupakan bagian dari tangkapan nelayan yang tidak dikehendaki atau bukan merupakan sasaran utama. Hasil tangkapan sampingan dibuang ke laut atau untuk konsumsi manusia dan hewan. Zeller dan Pauly (2005) menambahkan, hasil tangkapan sampingan yang dibuang menjadi permasalahan perikanan global. Tertangkapnya hasil tangkapan sampingan dapat menjadi ancaman bagi keanekaragaman spesies dan kelestarian lingkungan, sebab bagian dari tankapan ini biasanya tidak diatur. Dalam pengertian yang luas, hasil tangkapan sampingan mencakup semua hewan yang bukan merupakan sasaran utama bahkan termasuk benda-benda tidak hidup (sampah) yang tertangkap ketika melakukan operasi penangkapan (Eayrs 2005). 
Selanjutnya Eayrs (2005) mendefinisikan hasil tangkapan sampingan sebagai segala sesuatu yang bukan merupakan sasaran untuk ditangkap nelayan dan dapat terdiri dari penyu, ikan, kepiting, hiu, ikan pari, karang, rumput laut dan sampah dari dasar laut. Hasil tangkapan sampingan juga termasuk hewan-hewan dan benda tidak hidup yang berinteraksi dengan alat tangkap tetapi tidak sampai ke atas geladak kapal ikan. Hall et al. (2000) menyatakan hasil tangkapan sampingan merupakan masalah yang dapat mempengaruhi keberlanjutan perikanan tangkap.

Komposisi jenis hasil tangkapan sampingan alat penangkapan ikan gombang cukup bervariasi, yaitu mencapai 24 jenis spesies (Gambar 4). Kondisi ini Tentunya hal ini berpotensi untuk merusak keanekaragaman hayati dalam ekosistem perairan dimana alat tangkap tersebut dioperasikan. Hasil tangkapan sampingan juga telah menjadi perhatian utama untuk kegiatan konservasi (baik pemerintah dan non-pemerintah) masyarakat secara luas. Tentu saja profil, suara, dan pengaruh pada pendapat yang lebih luas dari hasil tangkapan sampingan tidak akan pernah kuat. Hasil tangkapan sampingan (bycatch) dan yang dibuang (discard) menjadi perhatian serius di level internasional. Hasil tangkapan sampingan tidak hanya mempengaruhi stok ikan di perairan, tetapi juga mempengaruhi rantai makanan dan habitat, dan pada akhirnya mengganggu dan merusak ekosistem (Harrington et al. 2005; Kelleher 2005 dan Zhou 2008).

Pendekatan ekosistem pengelolaan perikanan dikembangkan di seluruh dunia untuk menyesuaikan diri dengan prinsip pengelolaan perikanan berwawasan lingkungan. Ada banyak bukti bahwa kegiatan penangkapan ikan dapat mempengaruhi populasi spesies non-target (misalnya hasil tangkapan sampingan) dan menyebabkan dampak kerusakan fisik habitat dan ekosistem (Hall dan Mainprize 2005 dan Jennings 2005; 2007).

Harris dan Huang (2001) telah melakukan sebuah latihan simulasi di Teluk Carpentaria, Australia, dan menemukan bahwa pengurangan hasil tangkapan sampingan akan meningkatkan beberapa kelompok ikan, seperti piscivores bentik, piscivores bentho-pelagis, dan piscivores pelagis, tetapi dapat menurunkan biomassa udang. Dalam perikanan komersial, hasil tangkapan yang dibuang didefinisikan sebagai bagian dari bahan organik total dari hewan yang tertangkap dan dibuang ke laut untuk alasan apa pun. Hasil tangkapan sam- pingan yang dibuang kembali ke laut sebagian dimakan oleh hewan-hewan predator seperti ikan lumba-lumba dan burung laut (Svane 2005). Meskipun demikian, pembuangan hasil tangkapan sampingan secara luas dianggap sebagai tindakan yang bertentangan dengan tujuan konservasi perikanan dan laut di seluruh dunia (Kelleher 2005).

Eayrs (2005) hasil tangkapan yang dibuang adalah bagian dari hasil tangkapan sampingan yang dibuang atau dikembalikan ke laut dalam keadaan hidup atau mati. Termasuk semua hewan dan benda tidak hidup yang tersangkut dengan alat tangkap tetapi tidak sampai di geladak kapal. Hasil tangkapan sampingan yang dibuang terdiri dari spesies yang bernilai ekonomi rendah, spesies ikan komersial yang kecil-kecil, ikan muda dan sampah dari dasar laut.

Nelayan biasanya membuang bagian dari tangkapan ini, sebab tidak ekonomis untuk disimpan di kapal atau karena peraturan melarang jenis ikan ini didaratkan. Seringkali tangkapan spesies yang komersial, melebihi kapasitas pengolahan atau penyimpanan di kapal penangkapan sehingga kelebihan ini harus dibuang (Eayrs 2005).

Vestergaard (1996) menyatakan hasil tangkapan yang dibuang biasanya terjadi karena kekuatan nilai ekonomis (spesies non komersial dan spesies bernilai ekonomi rendah, karena kondisi dan ukurannya) dan juga sebagai akibat langsung dari tindakan manajemen (ukuran minimum pendaratan dan pembatasan pendaratan). Hall et al. (2000) menyatakan dengan alasan paling umum untuk membuang hasil tangkapan sampingan adalah spesies bernilai komersial rendah, kondisi hasil tangkapan buruk dan tangkapan kecil (di bawah ukuran minimum ukuran pendaran legal).

Membuang hasil tangkapan merupakan masalah global dalam bidang perikanan (Alverson et al. 1994). Membuang hasil tangkapan non-komersial dalam operasi penangkapan ikan di seluruh dunia adalah masalah yang telah menyita banyak perhatian. Pada tahun 1994, Organisasi Pangan dan Pertanian PBB (FAO) menerbitkan sebuah perkiraan tingkat pembuangan hasil tangkapan sampingan di seluruh dunia (Alverson et al. 1994). Hasil tangkapan sampingan yang tidak bernilai akan dibuang baik dalam keadaan hidup maupun dalam keadaan mati. Hal ini memicu permasalahan konservasi yang serius dikarenakan terbuangnya sumber daya alam yang berharga serta menyebabkan populasi spesies terancam lang- 
ka dan bahkan menjadi punah. Pengeksploitasian sumber daya laut secara lanjut akan mengakibatkan dampak perubahan terhadap ekosistem, keseluruhan jaringan trofik dan habitat (Crowder dan Murawski 1998).

Meskipun jumlah hasil tangkapan yang dibuang pada alat penangkapan ikan gombang kecil (Gambar 4), namun Watson dan Pauly (2001) menyatakan bahwa pembuangan hasil tangkapan sampingan yang tidak bernilai juga menghasilkan pemborosan substansi pada sumber makanan yang berpotensi. Hal inilah yang menyebabkan hasil tangkapan laut menurun secara global dan persaingan untuk pengurangan persediaan terus meningkat secara intensif (Watson dan Pauly 2001). Ahli ekologi, sosial dan ekonomi berargumen bahwa untuk mengurangi tangkapan perlu perhatian khusus dari pemerintah, industri dan masyarakat umum (Alverson dan Hughes 1996). Estimasi hasil tangkapan yang dibuang penting untuk menilai dampak menyeluruh dalam bidang perikanan seperti pada populasi ikan dan pada ekosistem dimana mereka mengoperasikan alat tangkap tersebut. Spesies hasil tangkapan yang dibuang bertahan hidup, mereka mempunyai ketahanan rendah dalam keberlangsungan hidupnya (Evans et al. 1994).

Selain bervariasinya jenis hasil tangkapan alat penangkapan ikan gombang yang dapat menjadi potensi perubahan struktur komoditas ikan dan udang serta juga dapat menjadi penyebab kerusakan sumberdaya perikanan, ukuran hasil tangkapan sampingan dan hasil tangkapan yang dibuang masih di bawah ukuran tingkat kedewasaan (under maturity size). Hal ini terindikasi dari banyaknya ikan-ikan kecil dan muda yang tertangkap (Gambar 5, 6, dan 7). Menurut Crowder dan Murawski (1998) dan Diamond et al. (1999) peningkatan kematian ikan muda dan juvenil akan memperlambat proses pemulihan sumberdaya di suatu perairan akibat kelebihan tangkap (overfishing). Selain itu, banyaknya jenis ikan, kepiting dan udang berukuran kecil dan muda tertangkap, tentunya akan bertolak belakang pula dengan konsep penangkapan ikan yang bertanggung jawab untuk perikanan yang berkelanjutan. Fenomena serupa juga dilaporkan oleh Cedrola et al. (2005); Borges et al. (2005), dan Fonseca et al. (2005) yang mana hasil tangkapan sampingan menjadi masalah pengelolaan perikanan tangkap komersial seperti: pukat, jaring lingkar dan semua jenis alat penangkapan ikan. Hasil tangkapan sampingan terdiri dari ikan muda yang belum dewasa, dan berpotensi menye- babkan stok perikanan di daerah perairan penangkapan menurun.

Upaya untuk dapat menurunkan hasil tangkapan sampingan (bycatch) dan hasil tangkapan yang dibuang (discard) perlu mempertimbangkan penggunaan jendela atau panel. Sebagai contoh adalah penggunaan bycatch excluder device (BED) atau Bycatch Reduce Device (BRD) untuk dapat mengeluarkan dan mengurangi hasil tangkapan sampingan selama proses penangkapan oleh alat tangkap gombang diperairan. Seperti halnya perikanan pukat udang di Nordic dengan menggunakan kerangka fiberglass dan kawat sebagai celah untuk keluarnya hasil tangkapan sampingan (Grimaldo dan Larsen 2005 dan Fonseca et al. 2005). Penggunaan panel pemisah dan jendela dengan mata jaring persegi empat pada mulut kantong pukat sebagai BRD dapat menurunkan hasil tangkapan sampingan ikan blue whiting sebanyak $73-74 \%$ dan ikan boarfish sebanyak 48-63\% (Fonseca et al. 2005). Ditambahkan lagi oleh van Marlen et al. (2005) penggunaan ukuran mata jaring yang lebih besar pada bagian mulut kantong akan dapat menurunkan hasil tangkapan sampingan dan memberikan peluang hidup lebih besar untuk hasil tangkapan sampingan yang dapat lolos dari mata jaring tersebut selama proses penangkapan berlangsung. Pendekatan rancangan dan konstruksi BRD atau BED untuk alat tangkap gombang dianggap lebih tepat mengacu kepada alat tangkap pukat. Hal ini disebabkan karena rancangan alat tangkap gombang ini sendiri mendekati bentuk alat tangkap pukat, yaitu berbentuk kerucut yang terdiri dari sayap yang berfungsi sebagai pengiring ikan dan udang masuk ke dalam kantong. Selain itu gombang juga memiliki badan, yang mana berfungsi menyatukan antara kantong dan sayap. Seluruh bagian tersebut juga dimiliki oleh alat tangkap pukat, tetapi yang membedakan atara pukat dan gombang ialah metode pengoperasiannya. Gombang dioperasikan secara pasif diperairan sedangkan pukat dioperasikan secara aktif mengejar sasaran tangkapan ikan.

\section{KESIMPULAN}

Berdasarkan komposisi, jenis hasil tangkapan gombang terdiri dari 33 spesies. Hasil tangkapan yang terbesar merupakan hasil tangkapan sampingan yaitu 24 spesies dari total spesies yang tertangkap atau $72,727 \%$. Selain itu alat tangkap gombang juga menghasilkan hasil tangkapan yang dibuang oleh nelayan ka- 
rena tidak memiliki nilai ekonomis dan tidak pula dapat dikonsumsi. Hasil tangkapan yang dibuang ini terdiri dari 3 spesies atau 9,091\%. Oleh karena itu, dapat disimpulkan alat tangkap gombang meskipun termasuk alat tangkap perikanan tradisional skala kecil ternyata dapat berpotensi untuk merubah struktur keanekaragaman hayati perairan.

\section{SARAN}

Berdasarkan ulasan kesimpulan di atas disarankan perlu penelitian terhadap rancangan dan konstruksi serta modifikasi alat tangkap gombang terutama untuk membuat bagian celah pelolosan hasil tangkapan sampingan (bycatch excluder device). Hal ini diharapkan nantinya dapat menurunkan jumlah dan jenis hasil tangkapan sampingan maupun hasil tangkapan yang dibuang pada setiap kali penarikan alat tangkap gombang.

\section{UCAPAN TERIMA KASIH}

Ucapan terima kasih disampaikan kepada Lembaga Penelitian dan Pengabdian Universitas Riau karena sudah memberikan dukungan dana DIPA LPPM Universitas Riau tahun 2017 untuk penelitian ini melalui skim Penelitian Unggulan Perguruan Tinggi. Terima kasih juga disampaikan kepada seluruh nelayan gombang dan Dinas Perikanan Kabupaten Bengkalis yang telah banyak memberikan bantuan selama pengumpulan data di lapangan.

\section{DAFTAR PUSTAKA}

Andrade HA, Pereira MD, Mayer FP. 2007. Alternative Methods for Calculating Catch-per-unit Effort for Skipjack Tuna (Katsuwonus pelamis) Caught in the Southwestern Atlantic Ocean Braz. J. Aquat. Sci.Technol. 1(2): 63-66.

Alverson DL, Freeberg MH, Pope JG, Murawski SA. 1994. A Global Assessment of Fisheries Bycatch and Discards. FAO Fisheries Technical Paper No. 339. Rome: FAO.

Alverson DL, Hughes S. 1996. Bycatch: from Emotion to Effective Natural Resource Management. Fish Biology and Fisheries. 6(4): 443-462.
Borges L, Rogan E, Officer R. 2005. Discarding by The Demarsal Fishery in The Waters Around Ireland. Fisheries Research. 76: 1-13.

Broadhurst MK, Millar RB, Wooden MEL, Macbeth WG. 2006. Optimising Codend Configuration in a Multispecies Demarsal Trawl Fishery. Fisheries Management and Ecology. 13: 81-92.

Cedrola PV, Gonzalez AM, Pettovello AD. 2005. Bycatch of Skates (Elasmobranchii: Arhynchobatidae, Rajidae) in The Patagonia Red Shrimp Fishery. Fisheries Research. 71: 141-150.

Crowder L, Murawski S. 1998. Fisheries Bycatch: Implications for Management. Fisheries 23(6): 8-16.

Diamond S, Crowder L, Cowell L. 1999. Catch and By-catch: The Qualitative Effects of Fisheries on Population Vital Rates of Atlantic Croaker. Transactions of the American Fisheries Society. 128: 10851105.

Eayrs S. 2005. A Guide to Bycatch Reduction in Tropical Shrimp-Trawl Fisheries. Rome, Italy: Food and Agriculture Organization (FAO) of the United Nations.

Evans SM, Hunter JE, Elizal, Wahju RI. 1994. Composition and Fate of The Catch and Bycatch in The Farne Deep (North Sea) Nephrops fishery. ICES J. Mar. Sci. 51: 155-168.

Fonseca $\mathrm{P}$, Campos A, Larsen RB, Borges TC, Erzini K. 2005. Using A Modified Nordmore Grid for By-catch Reduction in The Portuguese Crustacean-trawl Fishery. Fisheries Research. 71: 223-239.

Grimaldo E, Larsen RB. 2005. The Cosmos Grid: A New Design for Reducing Bycatch in The Nordic Shirp Fishery. Fisheries Research. 76: 187-197.

Hall MA, Alverson DL, Metuzal KI. 2000. Bycatch; Problems and Solutions: Seas at Millennium: An Environmental Evaluation. In: Sheppard, C.R. (Ed.), Global Issues and Processes.

Hall SJ, Mainprize BM. 2005. Managing Bycatch and Discards: How Much Progress Are We Making and How Can We Do Better? Fish Fish. 6(2): 134-155. 
Harrington JM, Myers RA, Rosenberg AA. 2005. Wasted Fishery Resources: Discard By-catch in the USA. Fish and Fisheries. 6: 350-361.

Harris A, Huang A. 2001. Assessing the Effect of Fishing on Non-target Species in Commonwealth Fisheries. Report to the Fisheries Resources Research Fund. Australian Department of Agriculture, Fisheries and Forestry, May 2001, Canberra.

Jennings S. 2005. Indicators to Support An Ecosystem Approach to Fisheries. Fish and Fisheries. 6: 212-232.

Jennings S. 2007. Reporting and Advising on the Effect of Fishing. Fish and Fisheries. 8: 269-276.

Kelleher K. 2005. Discards in the World's Marine Fisheries: An Update. FAO Fisheries Technical Paper No. 470. Rome, Italy: Food and Agriculture Organization of the United Nations.

Krebs, C. J. 1985. The Experimental Analysis of Distribution and Abudance. Ecology. New York: Harper dan Row.

Nofrizal, Yanase K, Arimoto T. 2009. Effect of Temperature on the Swimming Enduranceand Post-exercise Recovery of Jack Mackerel Trachurus japonicasas Determined by ECG monitoring. Fish Sci. 75: 1369-1375.

Nofrizal dan Arimoto T. 2011. ECG Monitoring on Swimming Endurance and Heart Rate Performance of Jack Mackerel, Trachurus japonicus for Repeated Exercise. The Journal of the Asian Fisheries Science. 24: 78-87.

Nofrizal, Ahmad M, Syofyan I. 2012. Tingkah Laku dan Kemampuan Renang Ikan Selais (Cryptopterus sp). Jurnal Iktiologi Indonesia. 11(2): 99-106.

Nofrizal. 2014. Aktivitas Jantung Ikan Nila, Oreochromis niloticus (Linnaeus, 1758) pada Kecepatan Renang yang Berbeda Dimonitor dengan Electrokardiograf (EKG). Jurnal Iktiologi Indonesia. 14(2): 101-109.
Nofrizal dan Ahmad M. 2015. Swimming Performance of Asian Redtail Catfish (Hemibagrusnemurus) in the Swimming Channel of Flume Tank. Journal Sustainable Science and Management. 10(1): 107-113.

Nofrizal. 2015. Kemampuan Renang Ikan Patin (Pangasius sutchi) di dalam Tanki Berarus. Jurnal Perikanan dan IImu Kelautan. 20(1): 43-51.

Nofrizal, Arimoto T. 2017. Histological Approach on the Lateral Line Organ of Jack Mackerel (Trachurus japonicas) for Mechanical Sensing in Swimming Behavior. Journal Sustainable Science and Management. 12(1): 23-29.

Syofyan I, Nofrizal 2005. Pengaruh Pengoperasian (Tidal Trap) terhadap Komunitas Ikan dan Udang di Perairan Bengkalis. Oral Presentation. Proceeding of Japan Society for Promotion Science (JSPS). Internasional Workshop on Eco-Friendly and Sustainable Fisheries. Hotel Ibis, Pekanbaru.

Svane IB. 2005. Occurrence of Dolphins and Seabirds and Their Consumption of Bycatch During Prawn Trawlingin Spencer Gulf, South Australia. Fish Res. 76(3): 317-327.

Van Marlen B, Bergman MJN, Groenewold S, Fonds M. 2005. New Approaches to The Reduction of Non-target Mortality in Beam Trawling. Fisheries Research. 72: 333-345.

Vestergaard N. 1996. Discard Behaviour, Highgrading and Regulation: The Case of the Greenland Shrimp Fishery. Mar. Resour. Ecol. 11: 247-266.

Watson R, Pauly D. 2001. Systematic Distortions in World Fisheries Catch Trends. Nature. 414(6863): 534-536.

Zeller D, Pauly D. 2005. Good News, Bad News: Global Fisheries Discards are Declining, but so are Total Catches. Fish and Fisheries. 6: 156-159.

Zhou S. 2008. Fishery By-catch and Discard: a Positive Perpective from Ecosystembased Fishery Management. Fish and Fisheries. 9: 308-315. 